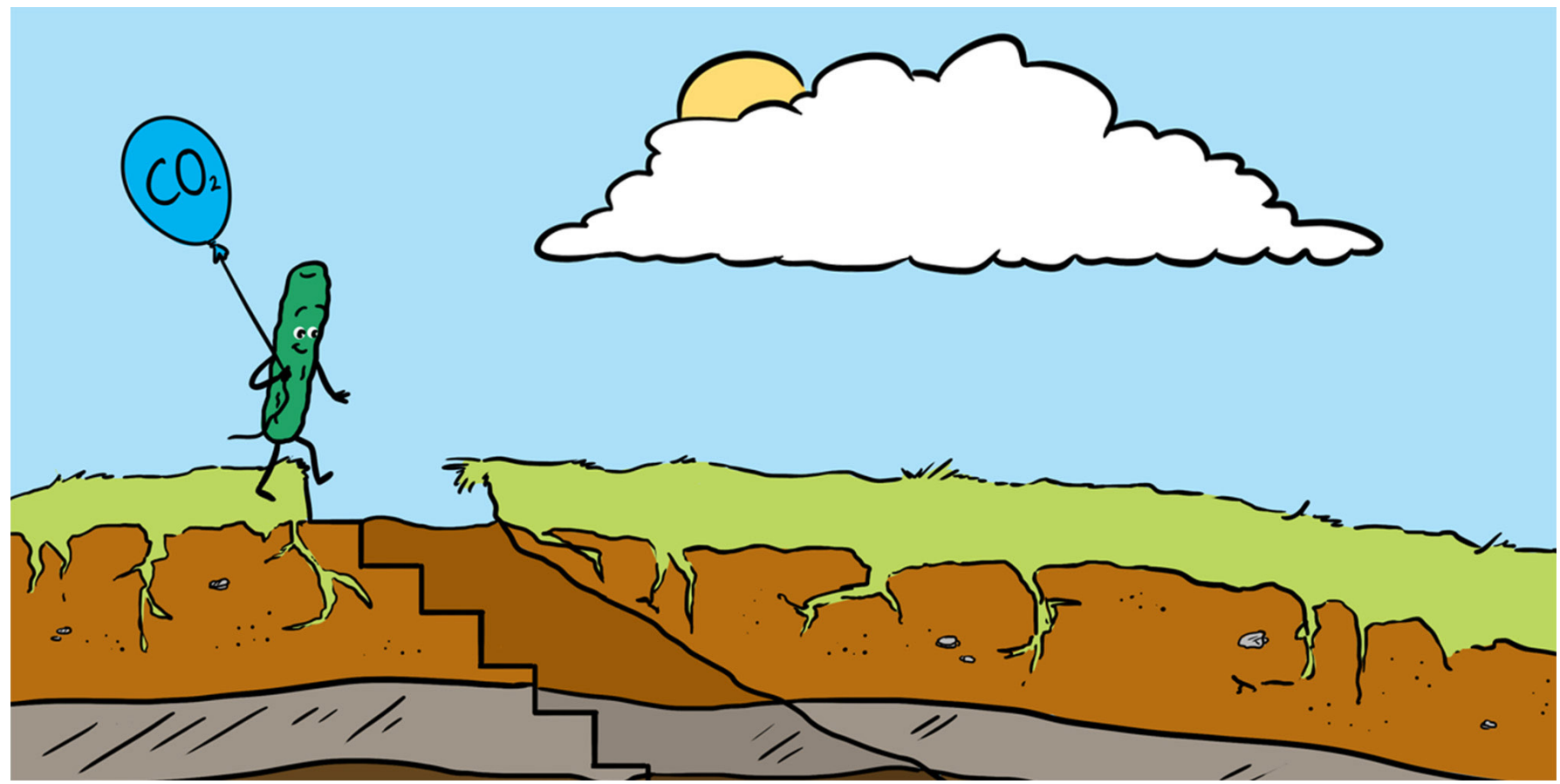

\title{
CAN BACTERIA LIVING UNDERGROUND HELP FIGHT CLIMATE CHANGE?
}

\section{Andre $\mathrm{Mu}^{1,2,3 *}$, and John W. Moreau 4}

Department of Microbiology and Immunology at the Peter Doherty Institute for Infection and Immunity, University of Melbourne, Melbourne, VIC, Australia

2 Doherty Applied Microbial Genomics, Department of Microbiology and Immunology at the Peter Doherty Institute for Infection and Immunity, University of Melbourne, Melbourne, VIC, Australia

${ }_{3}^{3}$ Microbiological Diagnostic Unit Public Health Laboratory, Melbourne, VIC, Australia

${ }^{4}$ School of Earth Sciences, University of Melbourne, Melbourne, VIC, Australia

\section{YOUNG REVIEWERS:}

LUKAN

Climate change can occur when chemicals called greenhouse gases enter the Earth's atmosphere. Carbon dioxide is one important greenhouse gas. A new technology to reduce the amount of greenhouse gases from entering Earth's atmosphere involves putting large amounts of carbon dioxide underground. Microbes, such as bacteria, are found almost everywhere on Earth, including in places many kilometers underground. Scientists combine skills from microbiology (the study of microbes), geology, and chemistry to understand how underground bacteria can help reduce greenhouse gases in the atmosphere and keep our planet healthy. 


\section{GREENHOUSE GASES}

Greenhouse gases are a type of gas that contributes to climate change. Carbon dioxide is an example of a greenhouse gas.

\section{CARBON CAPTURE} AND STORAGE

Carbon capture and storage is a technique being investigated by scientists as a way to reduce the impacts of climate change. The technique involves "catching" greenhouse gases before it enters Earth's atmosphere, and storing the gas deep underground.

\section{AQUIFER}

An aquifer is an underground layer of rock that contains water.

\section{Figure 1}

Aquifers are located deep under Earth's surface. An aquifer is an underground layer of rock that contains water. The aquifer used in this study was $1.4 \mathrm{~km}$ under Earth's surface.

Water samples collected from this aquifer were used in experiments to study whether injection of $\mathrm{CO}_{2}$ into the aquifer changed the populations of bacteria that live there.

\section{THERE ARE BACTERIA LIVING UNDERGROUND THAT ARE BEING EXPOSED TO GASES FROM THE ATMOSPHERE}

People need petrol (gasoline) or electricity to drive cars, watch television, or play games on their iPads. Chemicals called greenhouse gases are produced when we make petrol and electricity for people to use. Greenhouse gases can be harmful when they enter the Earth's atmosphere in large amounts, and they can cause problems for the environment. A large increase in greenhouse gases over a short period of time can cause changes in the world's weather patterns. These changes can cause the polar ice caps to melt and sea water levels to rise, which can flood cities close to the sea and leave people without homes.

Carbon dioxide $\left(\mathrm{CO}_{2}\right)$ is an important greenhouse gas. Scientists have noticed increases in $\mathrm{CO}_{2}$ in the atmosphere, due to human activity. One way that scientists can help reduce greenhouse gases in the atmosphere is known as "carbon capture and storage." Scientists can use special equipment to "catch" carbon dioxide before it enters the atmosphere, and then store the harmful gas deep underground.

There are places underground that can store large volumes of $\mathrm{CO}_{2}$ gas. These places are the nearly infinite number of tiny holes inside of rocks (Figure 1). The underground rocks form layers that go on for many kilometers in all directions and can be many meters thick. These layers are called aquifers. Aquifers contain water that can move around freely through the rocks, through the tiny holes. When the $\mathrm{CO}_{2}$ gas is injected into one of these aquifers, it can be stabilized so that it does not "leak" back into the atmosphere. The $\mathrm{CO}_{2}$ is stabilized when it becomes

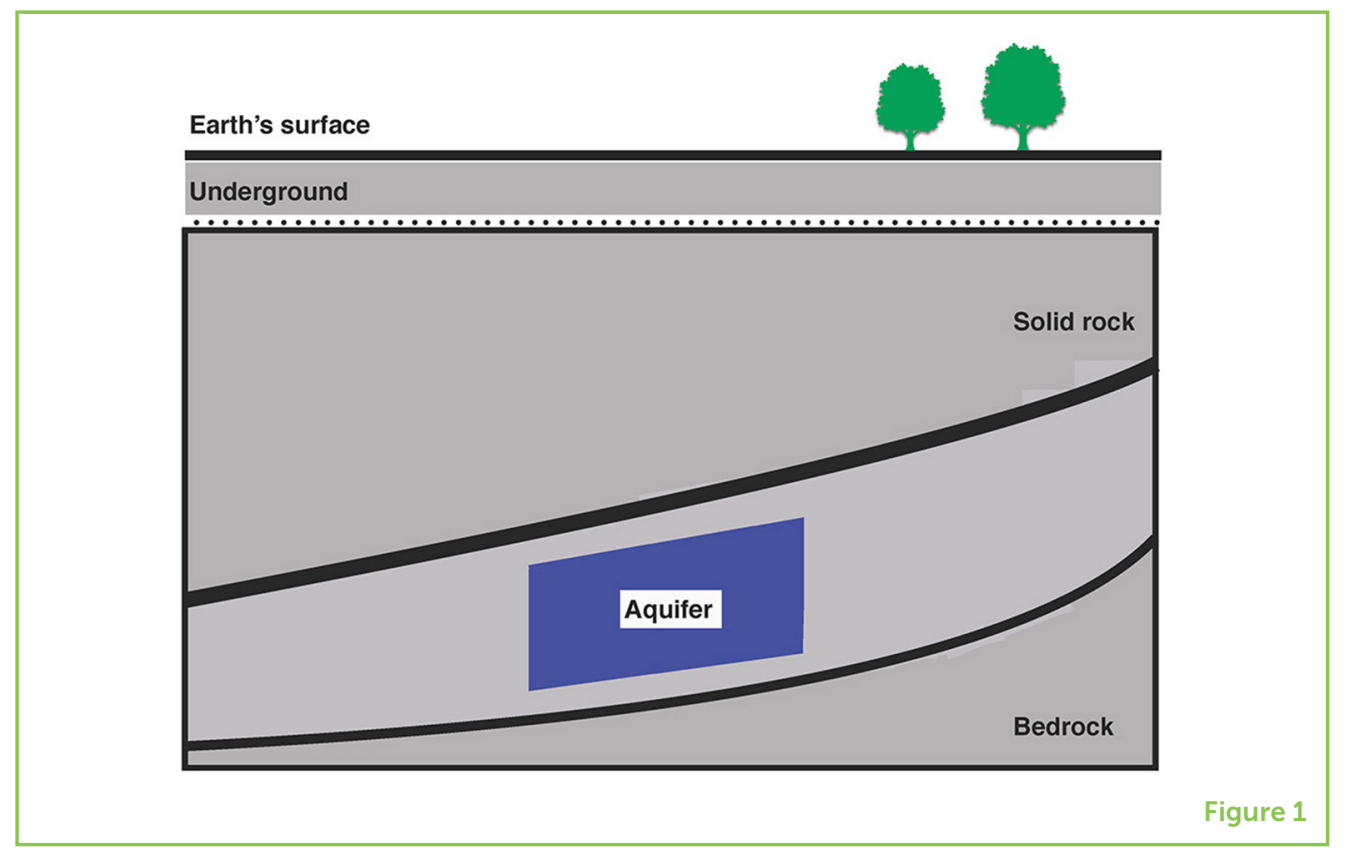




\section{Figure 2}

How do bacteria react to $\mathrm{CO}_{2}$ ? One of the key questions we asked in our study was: "How will the bacteria in the aquifer respond to injection of $\mathrm{CO}_{2}$ ?" While injection of $\mathrm{CO}_{2}$ into the aquifer may remove this greenhouse gas from the atmosphere, it is also possible that the bacteria living deep in the aquifer could convert the $\mathrm{CO}_{2}$ into a more harmful greenhouse gas, methane $\left(\mathrm{CH}_{4}\right)$, that might then be released into the atmosphere.

\section{BACTERIA}

Bacteria are microscopic organisms, and consist of just a single cell with simple structures.

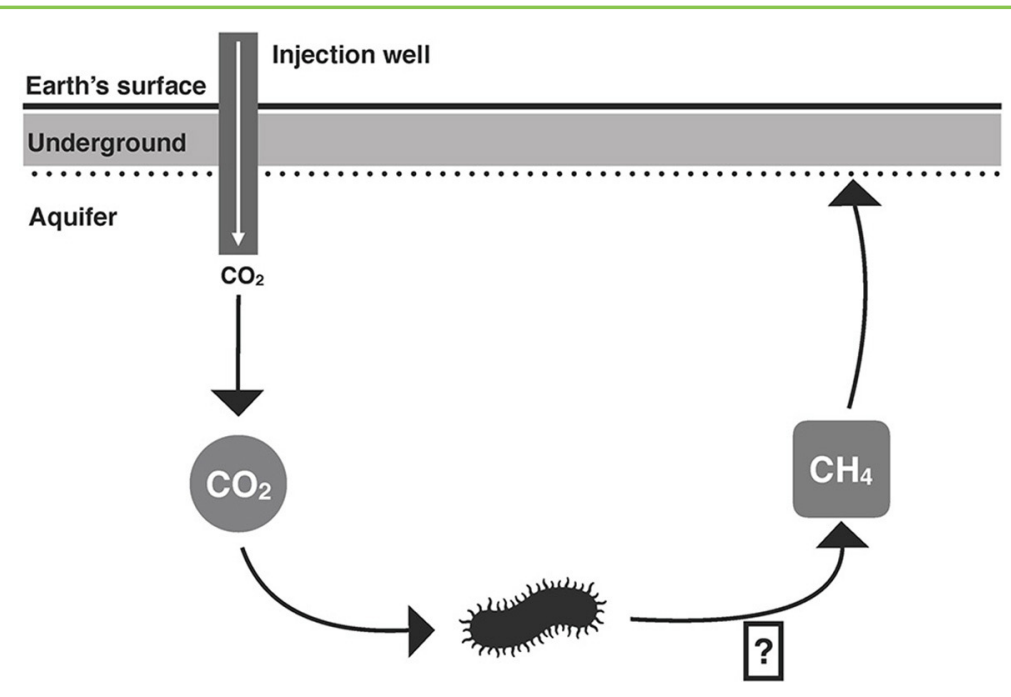

Figure 2

trapped inside the tiny holes of the rocks. Big outdoor experiments have shown that these aquifers can remain stable over long periods of time.

However, very little is known about how the $\mathrm{CO}_{2}$ affects the microbes that live underground. Microbes are microscopic organisms, including bacteria, which are the type of microbe we investigated in our experiments. It is important to understand how bacteria respond to underground $\mathrm{CO}_{2}$, because, through their metabolism, the bacteria can change the $\mathrm{CO}_{2}$ into a more harmful greenhouse gas called methane (Figure 2). Scientists do not want these underground bacteria to produce methane, because the methane can escape up into the atmosphere and make climate change worse. Therefore, the aim of our study was to understand how bacteria that live underground respond to $\mathrm{CO}_{2}$ gas being pumped into their "home" in a deep aquifer.

\section{DNA FROM BACTERIA HELPS SCIENTISTS UNDERSTAND HOW THEY RESPOND TO CO, MANY KILOMETERS UNDER THE GROUND}

Drs. John Moreau and Andre Mu are researchers at the University of Melbourne in Australia. John is trained in environmental chemistry, while Andre is a microbiologist who studies microbes, including bacteria. Together, they are experts at understanding how bacteria respond to large amounts of $\mathrm{CO}_{2}$ below Earth's surface. There are two main ways to determine how underground bacteria respond to $\mathrm{CO}_{2}$. We can (1) measure the changes in water chemistry in the aquifers; and (2) look at the different types of bacteria that are present before and after injecting $\mathrm{CO}_{2}$ gas underground (Figure 3). It is often difficult to grow these underground bacteria in the laboratory, because we do not fully understand what conditions they require to grow. Instead, we look 


\section{Figure 3}

What did we do and when did we do it? (A)

We collected water samples from the aquifer before injection of $\mathrm{CO}_{2}$, during the month of June, to understand the "baseline" conditions of the aquifer. Large amounts of $\mathrm{CO}_{2}$ were injected during the month of July and were allowed to settle underground. Samples were then collected for testing during August and September, to understand what $\mathrm{CO}_{2}$ did to both the water of the aquifer and the bacteria that live there. (B) DNA was extracted from the bacterial samples by: (1) filtering the water samples to collect the bacteria; (2) using a mixture of chemicals and glass beads to extract the DNA; (3) sequencing the DNA; and (4) using computers to help scientists understand which bacteria were present before and after $\mathrm{CO}_{2}$ injection.

\section{DNA}

Deoxyribonucleic acid is a molecule carrying the genetic instructions for life on Earth.

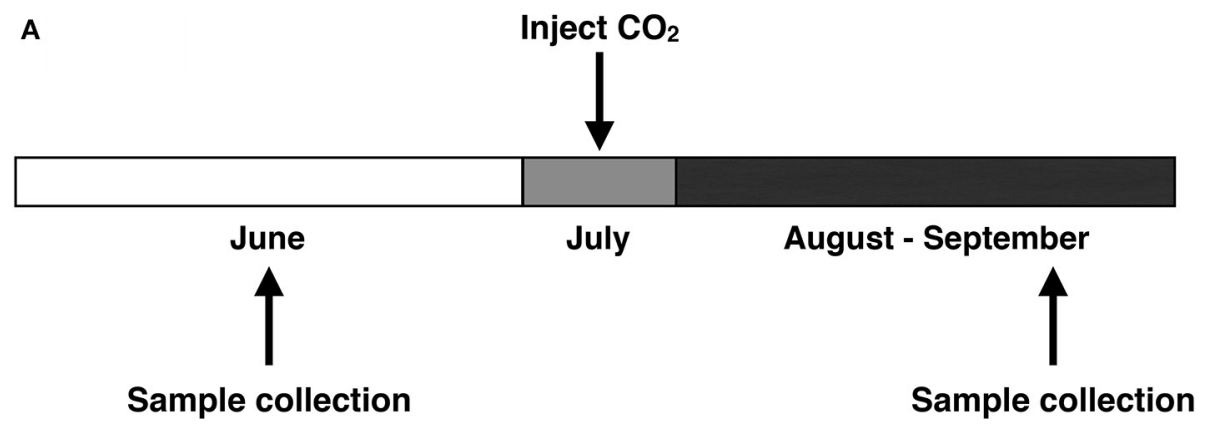

B

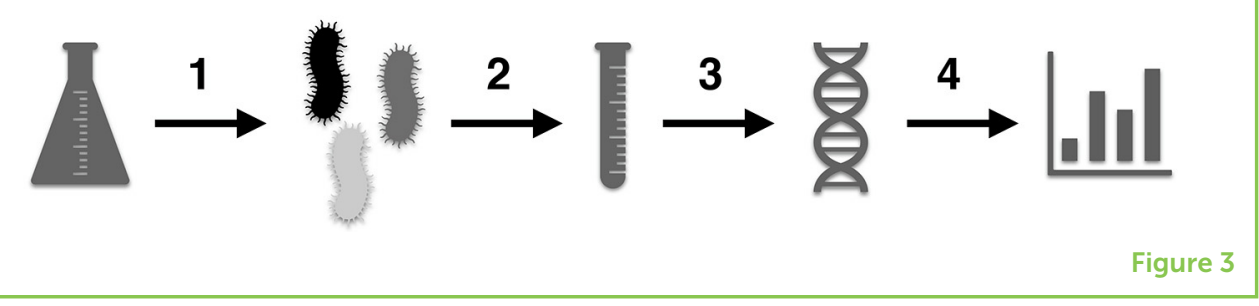

at the DNA from these bacteria, which can be collected without the need to grow them in the lab. DNA is a basic building block of life on Earth. Scientists use a combination of chemicals, very small glass beads, and a machine to carefully break the bacterial cells apart. The DNA is then collected from the cells and prepared for sequencing, which is a technique used to identify the order of the four different chemicals (abbreviated G, A, T, and C) that make up DNA (Figure 3). Understanding the DNA from our samples will give us an idea of the types of bacteria that live underground. The bacteria each have a unique DNA sequence that can be used to identify them, like a "fingerprint." The bacteria we identify can then be classified into groups. For example, some bacteria are autotrophs, which produce complex organic compounds from simple substances, and others are heterotrophs, which use the complex compounds produced by autotrophs for food/energy. It is important to understand how these two groups of bacteria interact with each other during the storage of $\mathrm{CO}_{2}$ gas in underground aquifers.

John and Andre teamed up with a group of scientists who are trained in geology and engineering, to perform a large experiment in the Otway Basin in Southeastern Australia. The experiment involved pumping 150 tons of $\mathrm{CO}_{2}$ gas more than one kilometer underground into an aquifer. That is almost the same distance as 10 football fields (Australian-rules football), and the weight of more than 2,000 football players! Water from the aquifer was collected before and after injecting the $\mathrm{CO}_{2}$ gas. These water samples were tested for different chemicals and conditions, such as $\mathrm{pH}$ and temperature. We also used high-powered computers to study the DNA of the bacteria present during the different stages of 
the experiment. We wanted to know if we would see the same groups of bacteria, or whether new groups would appear after the $\mathrm{CO}_{2}$ was injected deep into the aquifer.

\section{SOME BACTERIA RESPOND WELL TO THE INJECTED $\mathrm{CO}_{2^{\prime \prime}}$ WHILE OTHERS ARE NOT TOO HAPPY}

Two types of bacteria were present in the water samples in very low amounts before injecting the $\mathrm{CO}_{2}$ gas. These bacteria are called Comamonadaceae and Sphingomonadaceae. These two types of bacteria stayed at low numbers until large volumes of $\mathrm{CO}_{2}$ gas were pumped into the ground. Changes in the water chemistry occurred after injecting all the $\mathrm{CO}_{2}$ gas, and 41 days after $\mathrm{CO}_{2}$ injection, the numbers of Comamonadaceae and Sphingomonadaceae both increased. These two types of bacteria have the ability to produce gel-like communities, called biofilms, that act as a barrier to protect the bacterial cells from a changing environment. Increasing proportions of Comamonadaceae and Sphingomonadaceae after the injection of $\mathrm{CO}_{2}$ gas suggests that these types of bacteria can adapt to changes in water chemistry. Scientists believe that biofilms produced by bacteria can block holes and weak points in the aquifer, preventing $\mathrm{CO}_{2}$ gas from leaking back into the atmosphere, which is really important in order for this technique to be effective in reducing the amount of $\mathrm{CO}_{2}$ contributing to climate change.

We also found a type of bacteria called Carboxydocella in the aquifer water samples. Carboxydocella grows well in the conditions of the aquifer, where there is almost no oxygen, the pressure of the overlying rocks is 137 times more than what we feel on the surface of Earth, and temperatures are as high as $60^{\circ} \mathrm{C}\left(140^{\circ} \mathrm{F}\right)$. Carboxydocella is a type of autotroph. These bacteria can convert carbon monoxide (CO) from the environment to $\mathrm{CO}_{2}$, and they also produce hydrogen $\left(\mathrm{H}_{2}\right) \mathrm{mol}$ ecules. The $\mathrm{CO}_{2}$ and $\mathrm{H}_{2}$ are then used by other, heterotrophic bacteria as energy sources. Looking at the DNA we collected from our samples, we discovered that the percentage of Carboxydocella decreased and remained at low levels after the $\mathrm{CO}_{2}$ gas was injected into the Otway Basin. The decrease in Carboxydocella can change the bacterial community in ways that disrupt the storage of $\mathrm{CO}_{2}$ gas and may have negative impacts on the aquifer. This is an area of research that needs to be explored further by designing specific experiments in the laboratory. These experiments might include growing Carboxydocella under different concentrations of $\mathrm{CO}_{2}$ gas in the lab to determine what happens to this bacterium-can they slowly adapt to high $\mathrm{CO}_{2}$ concentrations, or will they disappear? What is clear, however, is that Carboxydocella plays an important role in cycling carbon, and supporting the growth of other bacteria living in the aquifer. 


\section{BACTERIA WORK TOGETHER AS A TEAM TO SUPPORT THE COMMUNITY}

Different types of bacteria in the environment tend to work together as a team. Bacteria support each other by making compounds that they share in order to stay alive. From our data, we hypothesize that when the groundwater becomes more acidic as a result of the $\mathrm{CO}_{2}$ mixing with water, the acidic environment promotes the growth of a group of bacteria that can use a chemical compound, called sulfide, as a source of energy. When this reaction combines with other chemicals in the aquifer, the conditions underground change, and promote the growth of a different group of bacteria, called sulfate-reducers. Sulfatereducers need $\mathrm{H}_{2}$ to make energy. Autotrophs, such as Carboxydocella, are a source of $\mathrm{H}_{2}$ for sulfate-reducers. Carboxydocella can also supply a group of bacteria known as methanogens with the $\mathrm{CO}_{2}$ and $\mathrm{H}_{2}$ they require to make methane. The injection of $\mathrm{CO}_{2}$ into aquifers may change the community of bacteria that live there. For example, Carboxydocella might disappear. If Carboxydocella disappears, then the ability of methanogens and sulfate-reducing bacteria to function might be lost as well. This might mean a change in how the $\mathrm{CO}_{2}$ is being stored, long term, in the aquifer.

\section{WHAT IS NEXT?}

By doing big experiments in the environment, we can understand what happens in the real world. We can then use this knowledge to create simple experiments in the laboratory to understand better what happens to $\mathrm{CO}_{2}$ gas, and how bacteria respond to $\mathrm{CO}_{2}$ that is injected underground. The next steps in this research are to perform experiments in the laboratory, in which we grow a certain group of bacteria found in many different aquifers, and expose them to high pressure, high temperature, and lots of $\mathrm{CO}_{2}$ gas. Through these experiments, we will learn how biofilms from Comamonadaceae and Sphingomonadaceae react to $\mathrm{CO}_{2}$. When we have a better understanding of how $\mathrm{CO}_{2}$ gas interacts with these bacteria, we can then make faster progress toward reversing the damaging effects of climate change.

\section{ACKNOWLEDGMENTS}

The authors acknowledge the support of the CO2CRC, and funding from the Commonwealth of Australia through the CO2CRC program for the original experiments. 


\section{ORIGINAL SOURCE ARTICLE}

Mu, A., Boreham, C., Leong, H. X., Haese, R. R., and Moreau, J. M. Changes in the deep subsurface microbial biosphere resulting from a field-scale $\mathrm{CO}_{2}$ geosequestration experiment. Front. Microbiol. (2014) 5:209. doi: 10.3389/fmicb.2014.00209

SUBMITTED: 28 March 2018; ACCEPTED: 20 December 2018; PUBLISHED ONLINE: 15 January 2019.

EDITED BY: Mark A. Brandon, The Open University, United Kingdom

CITATION: Mu A and Moreau JW (2019) Can Bacteria Living Underground Help Fight Climate Change? Front. Young Minds. 6:77. doi:10.3389/frym.2018.00077

CONFLICT OF INTEREST STATEMENT: The authors declare that the research was conducted in the absence of any commercial or financial relationships that could be construed as a potential conflict of interest.

COPYRIGHT () $2019 \mathrm{Mu}$ and Moreau. This is an open-access article distributed under the terms of the Creative Commons Attribution License (CC BY). The use, distribution or reproduction in other forums is permitted, provided the original author(s) and the copyright owner(s) are credited and that the original publication in this journal is cited, in accordance with accepted academic practice. No use, distribution or reproduction is permitted which does not comply with these terms.

\section{YOUNG REVIEWERS}

\section{LUKAN, AGE: 11}

I like fencing and playing video games.

TÉO, AGE: 14

I like badmington, ping pong, reading, and playing video games. 


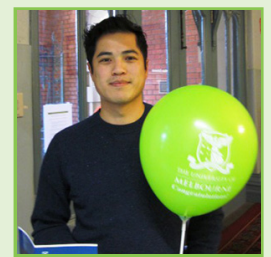

\section{AUTHORS}

\section{ANDRE MU}

Andre is a microbiologist. He is interested in studying microbes that are found in our gut, and also deep underneath Earth's surface. He is currently at the University of Melbourne (Australia), and was very lucky to have spent some time at the University of California San Diego (USA) as a visiting scholar. Andre works in the lab doing experiments, and also by his laptop interacting with high-powered computers analyzing large datasets. Andre enjoys cycling, playing futsal, watching Australian-rules football, and going to concerts. His favorite artist is Olafur Arnalds. *andre.mu@unimelb.edu.au

\section{JOHN W. MOREAU}

John is a geologist who later became a microbiologist, a "geo-microbiologist." He enjoys studying the natural world and how really really small things and processes can have really really big consequences for the planet and life. He likes to hike, swim, and spend time with his family. John grew up in Phoenix, AZ, experiencing the grandeur that is the geology of the southwestern U.S. His heroes are Ansel Adams, Bono, Roger Federer, and Yoda. 